\title{
Neoplasms of the salivary glands in a Turkish adult population
}

\author{
Muhammed İsa Kara ${ }^{1}$, Fahrettin Göze ${ }^{2}$, Şeref Ezirganlı ${ }^{3}$, Serkan Polat ${ }^{4}$, Suphi Muderris ${ }^{5}$, Sahende Elagoz ${ }^{2}$
}

${ }^{1}$ DDS, PhD. Assistant Professor, Department of Oral and Maxillofacial Surgery, Gaziantep University, Faculty of Dentistry, Gaziantep, Turkey

${ }^{2}$ MD. Professor, Department of Pathology, Cumhuriyet University, Faculty of Medicine, Sivas, Turkey

${ }^{3}$ DDS. Research Assistant, Department of Oral and Maxillofacial Surgery, Cumhuriyet University, Faculty of Dentistry, Sivas, Turkey

${ }^{4}$ DDS, PhD. AAssociate Professor Department of Oral and Maxillofacial Surgery, İnönü University, Faculty of Dentistry, Malatya, Turkey

${ }^{5}$ MD. Professor, Department of Otolaryngology, Cumhuriyet University, Faculty of Medicine, Sivas, Turkey

Correspondence:

Gaziantep University Faculty of Dentistry

27070, Gaziantep, Turkey

phismer@yahoo.com

Received: $31 / 08 / 2009$

Accepted: $25 / 03 / 2010$
Kara MI, Göze F, Ezirganli Ş, Polat S, Muderris S, Elagoz S. Neoplasms of the salivary glands in a Turkish adult population. Med Oral Patol Oral Cir Bucal. 2010 Nov 1;15 (6):e880-5.

http://www.medicinaoral.com/medoralfree01/v15i6/medoralv15i6p880.pdf

Article Number: $16960 \quad$ http://www.medicinaoral.com

(C) Medicina Oral S. L. C.I.F. B 96689336 - pISSN 1698-4447 - eISSN: $1698-6946$

eMail: medicina@medicinaoral.com

Indexed in:

-SCI EXPANDED

-JOURNAL CITATION REPORTS

-Index Medicus / MEDLINE / PubMed

-EMBASE, Excerpta Medica

-SCOPUS

-Indice Médico Español

\begin{abstract}
Objective: This retrospective study aimed to investigate the types and distribution of neoplasm of salivary glands in a Turkish population.

Study Design: The histological diagnosis records of the Department of Pathology at Cumhuriyet University were reevaluated for 125 patients who were treated for salivary gland tumors from 1987 to 2008. The neoplasms were analyzed for histological diagnosis, age, sex, and site. The histological diagnoses were analyzed according to the 2005 WHO classification.

Results: A total of 125 primary salivary gland neoplasms, consisting of 95 (76\%) benign and 30 (24\%) malignant groups were recorded. The most common major and minor salivary gland sites were the parotid $(61.6 \%)$ and palatal glands $(9.6 \%)$, respectively. Pleomorphic adenoma was the most frequent benign tumor followed by Warthin's tumor. Among the malignant group, adenoid cystic carcinoma was the most prevalent. Age for all cases ranged from 16-80 years; mean age was 41.97 years, with a female to male ratio of 1:1.15.

Conclusions: Although there were some discrepancies, the characteristics of salivary gland tumors of Turkish patients are in line with those of patients from other countries according to tumor type, tumor site distribution, and age and sex of patients.
\end{abstract}

Key words: Salivary gland, Turkish, neoplasms. 


\section{Introduction}

Salivary gland tumors are specific neoplasms in the oral and maxillo-facial area. However, morphological heterogeneity and low frequency make it considerably difficult to histologically classify these tumors $(1,2)$. The frequency of salivary gland neoplasms varies from 0.4 to 13.5 annual cases per 100000 inhabitants in various populations. Of all diagnosed neoplasms, salivary gland tumors constitute $3 \%$ of those in the head and neck area (3).

Salivary gland tumors are more frequent in adults than in children (4). Among all salivary gland tumors, the most frequently reported benign tumor is pleomorphic adenoma (1,3-15). Considering the malignant salivary gland neoplasms, reports of the most commonly seen tumor varies but, in general, mucoepidermoid carcinoma $(7,8,11,15-17)$ and adenoid cystic carcinoma $(5,6,9,12,18)$ were reported.

While tumors of the salivary glands can appear at any age, the maximum incidences is in the fourth decade of life for benign lesions and in the fifth decade for malignant tumors, although different authors consider the peak incidence correspond to the period between the fifth and seventh decades of life. Classically, these lesions have been reported to be more frequent in women, although the proportion varies according to the histological type of tumor (10).

Despite vast literature (1,3-18) reporting the prevalence of salivary gland tumors in patients from different countries, no substantial reports of these tumors was encountered among Turkish population. In addition to ethnicity and geographic location, the large variations also included the impact of different methods of registration (1).

The present study aimed to analyze the incidence and distribution of salivary gland tumors in a Turkish series, and provides data for comparison with previously published epidemiological studies from different geographical sites. Demographic data from these studies are vital for better understanding of the biological and clinical characteristics of the disease.

\section{Patients and methods}

This study covered the Department of Oral and Maxillofacial Surgery, Department of Otorhinolaryngology and Head and Neck Surgery of Cumhuriyet University and two different government hospitals' salivary gland neoplasm cases. During a 21-year period (1987-2008), 125 adult patients with primary neoplasm of the salivary gland were analyzed at the Pathology Department of Cumhuriyet University. The clinical and histopathological records were reviewed by the authors in consultation with a pathologist.

The major salivary glands involved the parotid gland, submandibular gland, and sublingual gland, whereas the minor glands included those in lip and intra-oral regions (the palate, lip, buccal cavity, floor of the mouth, and maxillary region).

The data were evaluated for all patients with surgically removed or biopsied pathologies of the salivary gland. All data were examined regarding histological diagnosis, age, sex, and site from which the biopsy was taken. The histological specimens were reviewed by a pathologist and ranked according to the WHO Classification of 2005.

Due to the nature of the study, little clinical information was available and therefore was not included in this study. Tumorlike lesions such as benign lymphoepithelial lesion, lymphoepithelial cyst, mucocele, ranula, salivary duct cyst, sarcoidosis, and sialidosis were excluded from the study.

\section{Results}

- Age and gender distribution

A total of 125 patients suffering from primary salivary gland neoplasm were identified, including 66 males, 57 females and 2 unclassified (Table 1). These data gave a ratio for female-to-male of 1:1.15. The patients' median age at the time of diagnosis was 41.97 with a range of 16-80 years. The peak occurrence of tumors was in the second decade for males and fifth for females. The average age of patients with benign tumor was 40.05 with a wide range from 16 to 75 years and peak incidence was between the second and fifth decades of life. The average age of patients with malignant tumor was 48.08 years of age with a wide range from 20 to 80 and peak incidence was between third and fifth decades of life (Table 1).

\section{- Anatomic location of the tumors}

In this study, all of the salivary gland tumors occurred unilaterally. The site distribution was as follows: 77 parotid glands, 20 submandibular glands, and 25 minor salivary gland tumors (Table 2). Locations of 3 of the tumors were not identified. There was no case of sublingual gland tumor. The palate $12(48 \%)$ was the most commonly affected site among the minor salivary gland tumors.

The parotid gland was the most common site of benign tumor involvement $(67.3 \%)$, followed by the submandibular gland (16.8\%), and the minor salivary gland (15.7\%). Benign minor salivary gland tumors showed a distinct predilection for the palate $(66.6 \%)$ followed by the lips $(26.6 \%)$, whereas they were rare in other regions $(6.6 \%)$. In the minor salivary glands, benign tumors $(60 \%)$ were more frequent than malignant tumors $(40 \%)$ (Table 2).

The parotid gland $(43.3 \%)$ was also the main site of occurrence of malignant tumors, followed by the minor salivary gland $(33.3 \%)$ and submandibular gland (\%13.3). The maxilla (50\%) was the most frequent site of the malignant minor salivary gland tumors. 
Of all the parotid gland neoplasms, pleomorphic adenoma was the most frequent tumor, constituting $68.8 \%$. The most frequent malignant tumor was adenoid cystic carcinoma (5.2\%) (Table 2). In the submandibular gland, the most frequent benign tumor was the pleomorphic adenoma (60\%). There were only four $(20 \%)$ malignant tumor occurrences seen in this area and each of these was different from the others according to histological type. In the minor salivary glands, the most frequent benign and malignant tumors were pleomorphic adenoma $(60 \%)$ and adenoid cystic carcinoma $(20 \%)$, respectively (Table 2).
- Tumor type

The overall frequency of benign tumors and malignant tumors was $76 \%$ and $24 \%$, respectively (Table 1 ). Pleomorphic adenoma was the most common type of tumor and constituted $84.2 \%$ of benign tumors and $64 \%$ of all tumors. Among the malignant salivary neoplasms, adenoid cystic carcinoma was the most prevalent at $36.6 \%$ of malignant tumors and $8.8 \%$ of all tumors, followed by adenocarcinoma not otherwise specified not otherwise specified (NOS) at $16.6 \%$ of malignant tumors and $4 \%$ of all tumors (Table 1 ).

Table 1. Age, gender, and diagnosis distribution of salivary gland neoplasm.

\begin{tabular}{|c|c|c|c|c|c|c|c|c|}
\hline Tumors & Male & Female & Unknown & $\begin{array}{c}\text { Age } \\
\text { (years) }\end{array}$ & $\begin{array}{c}\text { Age } \\
\text { range } \\
\text { (years) }\end{array}$ & Number & Percent & $\begin{array}{l}\text { Percent in } \\
\text { the group } \\
\text { (benign or } \\
\text { malignant) }\end{array}$ \\
\hline \multicolumn{9}{|l|}{ Benign tumours } \\
\hline Pleomorphic adenoma & 36 & 43 & 1 & 38.64 & $16-75$ & 80 & 64 & 84.2 \\
\hline Warthin's tumor & 6 & 0 & & 52.6 & $43-67$ & 6 & 4.8 & 6.3 \\
\hline Hemangioma & 2 & 1 & & 29.6 & $20-36$ & 3 & 2.4 & 3.1 \\
\hline Myoepithelioma & 2 & 0 & & 58 & $47-69$ & 2 & 1.6 & 2.1 \\
\hline Cystadenoma & 0 & 2 & & 41 & 41 & 2 & 1.6 & 2.1 \\
\hline Basal cell adenoma & 1 & 0 & & 74 & 74 & 1 & 0.8 & 1.0 \\
\hline Lipoma & 1 & 0 & & 36 & 36 & 1 & 0.8 & 1.0 \\
\hline Total & 48 & 46 & 1 & 40.05 & $16-75$ & 95 & 76 & 100 \\
\hline \multicolumn{9}{|l|}{ Malignant tumors } \\
\hline Adenoid cystic carcinoma & 8 & 3 & & 46.5 & $20-68$ & 11 & 8.8 & 36.6 \\
\hline Adenocarcinoma NOS & 3 & 2 & & 39 & $30-49$ & 5 & 4 & 16.6 \\
\hline $\begin{array}{l}\text { Mucoepidermoid carci- } \\
\text { noma }\end{array}$ & 2 & 1 & & 42 & $23-63$ & 3 & 2.4 & 10.0 \\
\hline $\begin{array}{l}\text { Carcinoma ex-pleomor- } \\
\text { phic adenoma }\end{array}$ & 1 & 1 & & 21 & 21 & 2 & 1.6 & 6.6 \\
\hline $\begin{array}{l}\text { Adenosquamous carci- } \\
\text { noma }\end{array}$ & 2 & 0 & & 65.5 & $61-70$ & 2 & 1.6 & 6.6 \\
\hline Squamous cell carcinoma & 0 & 2 & & 58 & $36-70$ & 2 & 1.6 & 6.6 \\
\hline $\begin{array}{l}\text { Undifferantiated carci- } \\
\text { noma }\end{array}$ & 1 & 1 & & 69 & $58-80$ & 2 & 1.6 & 6.6 \\
\hline $\begin{array}{l}\text { Polimorphous low grade } \\
\text { adenocarcinoma }\end{array}$ & 0 & 0 & 1 & - & - & 1 & 0.8 & 3.3 \\
\hline Salivary duct carcinoma & 1 & 0 & & 33 & 33 & 1 & 0.8 & 3.3 \\
\hline Acinic cell carcinoma & 0 & 1 & & 71 & 71 & 1 & 0.8 & 3.3 \\
\hline Total & 18 & 11 & 1 & 48.08 & $20-80$ & 30 & 24 & 100 \\
\hline
\end{tabular}

NOS: not otherwise specified 
Table 2. Histological diagnosis and site distribution of salivary gland neoplasms ( $\mathrm{n}=125)$.

\begin{tabular}{|c|c|c|c|c|c|c|c|c|c|c|c|c|c|c|}
\hline \multirow[b]{3}{*}{ Benign tumors } & \multicolumn{11}{|c|}{ Salivary gland } & \multirow[b]{3}{*}{ Unknown } & \multirow[b]{3}{*}{$\begin{array}{c}\text { Grand } \\
\text { total }\end{array}$} & \multirow[b]{3}{*}{$\%$} \\
\hline & \multicolumn{4}{|c|}{ Major } & \multicolumn{7}{|c|}{ Minor } & & & \\
\hline & Parotid & $\%$ & SM & $\%$ & Palate & Lip & Buccal & Maxillary & $\begin{array}{c}\text { Floor of } \\
\text { the mouth }\end{array}$ & Total & $\%$ & & & \\
\hline Pleomorphic adenoma & 53 & 68.8 & 12 & 60 & 10 & 4 & 1 & & & 15 & 60 & & 80 & 64 \\
\hline Warthin's tumor & 5 & 6.5 & 1 & 5 & & & & & & & & & 6 & 4.8 \\
\hline Hemangioma & 2 & 2.6 & 1 & 5 & & & & & & & & & 3 & 2.4 \\
\hline Cystadenoma & & & 2 & 10 & & & & & & & & & 2 & 1.6 \\
\hline Myoepithelioma & 2 & 2.6 & & & & & & & & & & & 2 & 1.6 \\
\hline Basal cell adenoma & 1 & 1.3 & & & & & & & & & & & 1 & 0.8 \\
\hline Lipoma & 1 & 1.3 & & & & & & & & & & & 1 & 0.8 \\
\hline Total & 64 & 83.1 & 16 & 80 & 10 & 4 & 1 & & & 15 & 60 & & 95 & 76 \\
\hline \multicolumn{15}{|l|}{ Malignant tumors } \\
\hline $\begin{array}{l}\begin{array}{l}\text { Adenoid cystic } \\
\text { carcinoma }\end{array} \\
\end{array}$ & 4 & 5.2 & 1 & 5 & 1 & 1 & & 2 & 1 & 5 & 20 & 1 & 11 & 8.8 \\
\hline Adenocarcinoma NOS & 2 & 2.6 & & & & & & 2 & & 2 & 8 & 1 & 5 & 4 \\
\hline $\begin{array}{l}\text { Mucoepidermoid } \\
\text { carcinoma }\end{array}$ & 1 & 1.3 & 1 & 5 & & & & 1 & & 1 & 4 & & 3 & 2.4 \\
\hline $\begin{array}{l}\text { Carcinoma } \\
\text { expleomorphic adenoma }\end{array}$ & 1 & 1.3 & 1 & 8.3 & 1 & & & & & 1 & 4 & & 2 & 1.6 \\
\hline \begin{tabular}{|l|}
$\begin{array}{l}\text { Adenosquamous } \\
\text { carcinoma }\end{array}$ \\
\end{tabular} & 1 & 1.3 & & & & 1 & & & & 1 & 4 & & 2 & 1.6 \\
\hline Squamous cell carcinoma & 1 & 1.3 & 1 & 1.2 & & & & & & & & & 2 & 1.6 \\
\hline $\begin{array}{l}\text { Undifferantiated } \\
\text { carcinoma }\end{array}$ & 2 & & & & & & & & & & & & 2 & 1.6 \\
\hline $\begin{array}{l}\text { Polimorphous low grade } \\
\text { adenocarcinoma }\end{array}$ & & & & & & & & & & & & 1 & 1 & 0.8 \\
\hline Salivary duct carcinoma & & & 1 & 5 & & & & & & & & & 1 & 0.8 \\
\hline Acinic cell carcinoma & 1 & 1.3 & & & & & & & & & & & 1 & 0.8 \\
\hline Total & 13 & 16.9 & 4 & 20 & 2 & 2 & & 5 & 1 & 10 & 40 & 3 & 30 & 24 \\
\hline Grand Total & 77 & 100 & 20 & 100 & 12 & 6 & 1 & 5 & 1 & 25 & 100 & 100 & 125 & 100 \\
\hline
\end{tabular}

NOS: not otherwise specified

\section{Discussion}

Salivary glands tumors are specific in the oral and maxillofacial region, corresponding to approximately 3\% to $10 \%$ of neoplasms of this area (11). Although demographic data from these studies makes understandable the biological and clinical characteristics of the disease (6), the lack of a nation-wide population-based neoplasm registry was encountered in Turkey, which makes it impossible to give any prevalence values for salivary gland neoplasms in this country. This study provides data for comparison with other epidemiological studies from different geographical sites and races.

During 1987-2008, 125 patients with salivary gland tumors were diagnosed and treated in this hospital; almost all of them received surgical treatment. In the primary tumors, the benign: malignant ratio was 3.16:1. The ratios from similar studies in other countries ranged from 1.34:1 in China (1), 1.6:1 in India (6), 2.33:1 in Jordan (9), 4:1 in Brazil (11), and 5.36:1 in the US (15).

Pleomorphic adenoma was the most commonly encountered type of salivary gland neoplasm, which is in agreement with findings from all of the published literature from all over world (1,3-15). The incidence of pleomorphic adenoma has been reported to range from between $40.8 \%$ and $70 \%$ (9). Of all the lesions, pleomorphic adenoma constituted $64 \%$ followed by Warthin's tumor $4.8 \%$, and then hemangioma at $2.4 \%$. The report according to the prevalence of malignant salivary gland tumor was various. Some authors $(7,8,11,15-17)$ have reported that mucoepidermoid carcinoma is the most frequent malignant salivary tumor. In contrast to these studies, in the present study, adenoid cystic carcinoma was the most frequent malignant tumor found, which corroborates reports by Toida et al. (5), Subhashraj (6), Al-Khateeb et al. (9), Kamulegeya et al. (12), and Rapidis et al. (18).

Of all salivary gland tumors included in this study, $61.6 \%$ were located in the parotid gland, $16 \%$ in the submandibular gland, $20 \%$ in the minor salivary glands and $2.4 \%$ were unknown. This result is similar to findings of most of the published reports $(1,6,9)$. However, according to Vargas's et al. (11) report, the submandibu- 
lar gland is the most frequent, affecting other areas than minor salivary glands. Furthermore, Kamulegeya et al. (12) reports that the palate is the most commonly affected area of the salivary gland tumors. Of the minor salivary gland sites, the palate was the most frequently affected. This is consistent with previously reported studies (1,3-18).

In almost all published studies, the parotid gland was the predominant area of the benign tumors (1,3-20), with which we agree (83.1\%). The present study also confirms previous reports that the pleomorphic adenomas $(68.8 \%)$ are more frequently seen than any other group of parotid gland's tumors. Although there is no consensus in the literature according to parotid gland malignancies, the majority of reports found that mucoepidermoid carcinoma is the most frequent parotid gland malignancy $(1,6,11,15)$. According to Al-Khateeb's et al. (9) report, the frequency of mucoepidermoid carcinoma and adenoid cystic carcinoma originating from the parotid gland was equal. On the other hand, other series have reported adenoid cystic carcinoma (12), carcinoma ex pleomorphic adenoma (19), squamous cell carcinoma (8), and acinic cell carcinoma (20) as the most common parotid gland malignancy. In contrast to the literature, in this study, the most frequent malignant tumor in the parotid gland was adenoid cystic carcinoma (5.2\%).

In the submandibular gland, we found that the most common benign tumor was pleomorphic adenoma, which is consistent with the all of the previously published reports $(8,11,12)$. On the other hand, there are small numbers of malignant salivary tumors affecting the submandibular gland. In this series, only three malignant cases were seen in this area, including adenoid cystic carcinoma, mucoepidermoid carcinoma, and salivary duct carcinoma. The literature shows that adenoid cystic carcinoma is the most frequent malignant tumor of the submandibular gland $(1,6,9)$.

Pleomorphic adenoma (60\%) was the most frequent tumor of the minor salivary glands, in agreement with the literature (1,3-15). Adenoid cystic carcinoma (20\%) was the most commonly encountered malignant tumor in the minor salivary glands. Although a great number of reports $(1,5,6,8,9)$ corroborate our study, according to some reports $(7,11)$, mucoepidermoid carcinomas were the most common malignant minor salivary gland tumors. In contrast to other studies, van Heerden et al. (14) reported that polymorphous low-grade adenocarcinoma was the most common malignant tumor. In this study, no cases of sublingual gland tumors were found. This confirms the rarity of salivary tumors at this site.

The average age at the time of diagnosis for salivary gland neoplasms was 41.97 and ranged from 16-80. The reports, according to the mean age of salivary gland neoplasms in the literature, were those of Al-Khateeb et al. (9) [40 years], Li et al. (1) [41.38 years], Subhashraj
(6) [46 years], Vargas et al. (11) [48 years], and Kamulegeya et al. (12) [34 years]. There was a slight overall male predominance, with a male to female ratio of 1.15:1. This finding coincides with some reports $(6,8)$, but differs from the majority of studies that showed a higher frequency among females $(1,9,11,12)$.

In benign tumors, basal cell adenoma, and lipoma occurred in one each case. In malignant tumors, there was only one case from some of each group, which were acinic cell carcinoma, salivary duct carcinoma, and polymorphous low-grade adenocarcinoma. Because of polimorphous low-grade adenocarcinoma described as recently as 1983, earlier reports did not recognize this tumor. It was estimated that this tumor may have been diagnosed as adenoid cystic carcinoma. In our reports, only one case was found. In the literature, although some of the articles $(14,20)$ reported high incidence of these tumors, several studies $(5,11,13)$ found no cases of these tumors.

\section{Conclusion}

Although there were some discrepancies, the patients who presented salivary gland neoplasms to the Pathology Department of Cumhuriyet University (1987-2008) showed that many clinical characteristic of the disease were in agreement with most of studies. Discrepancies may be explained by the geographic differences, the genetic background of the patients, and differences in exposure to etiological factors.

\section{References}

1. Li LJ, Li Y, Wen YM, Liu H, Zhao HW. Clinical analysis of salivary gland tumor cases in West China in past 50 years. Oral Oncol. 2008; $44: 187-92$.

2. Minicucci EM, de Campos EB, Weber SA, Domingues MA, Ribeiro DA. Basal cell adenoma of the upper lip from minor salivary gland origin. Eur J Dent. 2008;2:213-6.

3. Wang D, Li Y, He H, Liu L, Wu L, He Z. Intraoral minor salivary gland tumors in a Chinese population: a retrospective study on 737 cases. Oral Surg Oral Med Oral Pathol Oral Radiol Endod. 2007;104:94-100.

4. Dhanuthai K, Sappayatosok K, Kongin K. Pleomorphic adenoma of the palate in a child: a case report. Med Oral Patol Oral Cir Bucal. 2009;14:E73-5.

5. Toida M, Shimokawa K, Makita H, Kato K, Kobayashi A, Kusunoki Y, et al. Intraoral minor salivary gland tumors: a clinicopathological study of 82 cases. Int J Oral Maxillofac Surg. 2005;34:528-32.

6. Subhashraj K. Salivary gland tumors: a single institution experience in India. Br J Oral Maxillofac Surg. 2008;46:635-8.

7. Yih WY, Kratochvil FJ, Stewart JC. Intraoral minor salivary gland neoplasms: review of 213 cases. J Oral Maxillofac Surg. 2005;63:80510.

8. Otoh EC, Johnson NW, Olasoji H, Danfillo IS, Adeleke OA. Salivary gland neoplasms in Maiduguri, north-eastern Nigeria. Oral Dis. 2005;11:386-91.

9. Al-Khateeb TH, Ababneh KT. Salivary tumors in north Jordanians: a descriptive study. Oral Surg Oral Med Oral Pathol Oral Radiol Endod. 2007;103:e53-9.

10. Pons Vicente O, Almendros Marqués N, Berini Aytés L, Gay Escoda C. Minor salivary gland tumors: A clinicopathological study of 18 cases. Med Oral Patol Oral Cir Bucal. 2008;13:E582-8. 
11. Vargas PA, Gerhard R, Araújo Filho VJ, de Castro IV. Salivary gland tumors in a Brazilian population: a retrospective study of 124 cases. Rev Hosp Clin Fac Med Sao Paulo. 2002;57:271-6.

12. Kamulegeya A, Kasangaki A. Neoplasms of the salivary glands: a descriptive retrospective study of 142 cases-Mulago Hospital Uganda. J Contemp Dent Pract. 2004;5:16-27.

13. Rivera-Bastidas H, Ocanto RA, Acevedo AM. Intraoral minor salivary gland tumors: a retrospective study of 62 cases in a Venezuelan population. J Oral Pathol Med. 1996;25:1-4.

14. Van Heerden WF, Raubenheimer EJ. Intraoral salivary gland neoplasms: a retrospective study of seventy cases in an African population. Oral Surg Oral Med Oral Pathol. 1991;71:579-82.

15. Pinkston JA, Cole P. Incidence rates of salivary gland tumors: results from a population-based study. Otolaryngol Head Neck Surg. 1999;120:834-40.

16. Li Y, Li LJ, Huang J, Han B, Pan J. Central malignant salivary gland tumors of the jaw: retrospective clinical analysis of 22 cases. $\mathrm{J}$ Oral Maxillofac Surg. 2008;66:2247-53.

17. Curry JL, Petruzzelli GJ, McClatchey KD, Lingen MW. Synchronous benign and malignant salivary gland tumors in ipsilateral glands: a report of two cases and a review of literature. Head Neck. 2002;24:301-6.

18. Rapidis AD, Stavrianos S, Lagogiannis G, Faratzis G. Tumors of the submandibular gland: clinicopathologic analysis of 23 patients. $J$ Oral Maxillofac Surg. 2004;62:1203-8.

19. Eveson JW, Cawson RA. Salivary gland tumours. A review of 2410 cases with particular reference to histological types, site, age and sex distribution. J Pathol. 1985;146:51-8.

20. Van der Wal JE, Leverstein H, Snow GB, Kraaijenhagen HA, Van der Waal I. Parotid gland tumors: histologic reevaluation and reclassification of 478 cases. Head Neck. 1998;20:204-7. 